\title{
Readiness of Health Faculty Students Towards the Implementation of Interprofessional Education
}

\author{
Laila Isrona ${ }^{1, *}$ Rika Susanti $^{2}$ \\ ${ }^{1}$ Medical Education Unit, Faculty of Medicine, University of Andalas, West Sumatera Indonesia \\ ${ }^{2}$ Forensic Department, Faculty of Medicine, University of Andalas, West Sumatera, Indonesia \\ ${ }^{*}$ Corresponding author. Email: lailaisrona@med.unand.ac.id
}

\begin{abstract}
Interprofessional Education (IPE) is defined as two or more professional learnings altogether to improve the collaboration and quality. The IPE is also a solution to the issue of professional fragmentation. Health faculties around the world already implement IPE into their curricula to improve of health care services. In contrary, University of Andalas is still on the planning stage to implement IPE where there is a necessity towards readiness data. This was a cross sectional quantitative study to assess the readiness of health faculty students toward the implementation IPE by using Readiness Interprofessional Learning Scale (RIPLS) as its instrument. A total of 756 students from health faculties at Andalas University, including eight majors in medical and health, were participated in this study. Mostly the subjects were female $(84.39 \%)$ with the majority of age group between 20-24 years old (58.73). The students in every major mostly shown good readiness which imply that they are ready to implement IPE in their leaning. However, there was a student marked poor for readiness. For each domain in RIPLS, most students in every major also scored well. They shared similar opinion for each domain. This study could describe the profile of readiness towards IPE implementation. But, this study could not determine any related factors to students' readiness.
\end{abstract}

Keywords: Health Faculty, Interprofessional Education, Readiness Interprofessional Learning Scale, Student

\section{INTRODUCTION}

Interprofessional Education (IPE) is defined as two or more professions learned altogether to improve the collaboration and quality of health care with patient centred service as the concept of learning and collaborative practice. [1][2] It is a good solution provided to prepare collaboration skills as health care providers to get them ready to run collaborative practice in health services. [1]

There are three compulsory requirements for educational institution to implement IPE which include knowledge and skill, benefit to gain, and institutional support. The competencies included in IPE based on data from helath faculty students and lecturers around Indonesia can be seen in Table 1. [3][4]

The existence of IPE becomes important to solve the issue of professional fragmentation and improving patients' outcomes in the provision of patient-centred care. [5]-[7] It also improved the knowledge and professional skills of healthcare personals.[6][8] In order to actualize that, we need to apply appropriate teaching/learning method in IPE. [7] The institution around the world had been trying to integrate IPE into their curriculum. The global changes, including the emergence of new diseases, accompanied by complexity of health care globally, has pushed the implementation of IPE internationally.[1]
Table 1. IPE's competencies

\begin{tabular}{|c|c|}
\hline Competency & Component \\
\hline Knowledge & $\begin{array}{l}\text { Understanding the } \\
\text { roles/competencies of } \\
\text { each professions respectively. } \\
\text { Understanding duties and authorities } \\
\text { of each professions } \\
\text { Having personal skill }\end{array}$ \\
\hline Skill & $\begin{array}{l}\text { Effective } \\
\text { communication } \\
\text { Group dynamic } \\
\text { Organizational } \\
\text { skill/leadership } \\
\text { Understanding social knowledge/able } \\
\text { to socialize } \\
\text { Highly respect the ethic }\end{array}$ \\
\hline Attitude & $\begin{array}{l}\text { Eliminate superiority towards certain } \\
\text { professions } \\
\text { Confidence towards own profession }\end{array}$ \\
\hline Teamwork & $\begin{array}{l}\text { Teamwork } \\
\text { Interprofessional collaboration } \\
\text { Mutual needs }\end{array}$ \\
\hline
\end{tabular}

ASEAN's countries are included in the list. However, the developments of IPE in each country are different. Singapore already have a well maintained IPE program, furthermore they also create a sustainable IPE's platform for ASIAN university. [9][10] While another study in Lao People's Democratic Republic show the IPE in one of the university is still in the form of initial implementation.[11] Scoping down to Indonesia, several journals have been publishing the study related to the implementation of IPE in medical and health curricula, assessing the outcomes 
and giving suggestion for further development in faculties. [7][11]-[15]

In the Andalas University, IPE is not implemented yet. In order to implement it, data of internal stakeholders' readiness are needed. The only study related to IPE and readiness towards its implementation at Andalas University was performed by Devenski et.al. [3] , in the Faculty of Medicine. The topic was students' readiness toward the implementation of IPE. The study showed 82\% students were in good category of readiness towards IPE implementation while the lecturers also ready to implement IPE but in need for further socialization, preparation with institutional support. [3]

\section{METHOD}

\subsection{Design and Sample}

This was a cross-sectional study with quantitative method conducted from June 2019 until December 2019 at Andalas University, West Sumatera, Indonesia. We aimed to assess the readiness of students in health faculties towards the future implementation of IPE by using modified Readiness Interprofessional Learning Scale (RIPLS).

We performed the study to the registered students at the Health Faculties in odd semester, academic year 2019/2020. There were five faculties included, the Faculty of Medicine, Faculty of Dentistry, Faculty of Pharmacy, Faculty of Nursing and Faculty of Public Health with eight majors in total, covering up to clinical phase students. Those majors were medical, dentistry, nursing, midwifery, pharmacy, public health, nutrition and psychology. However, the public health, nutrition, and psychology have no clinical phase in their curriculum unlike the other five.

The sample size was determined by using proportional random sampling from the total of 4,747 students in population. The minimum sample size was counted as 407 students.

\subsection{The Instrument of Study}

The readiness of students was measured by using modified RIPLS. It was a 19-questions questionnaire with 5 points Likert scale which were divided into favourable (positive) questions and unfavourable (negative) questions. The items explored three aspects of interprofessional education. First, the recognition of teamwork and collaboration, along with the content and method for subjects to work on Interprofessionally. Second, exploring the positive and negative aspects of professional identity. Lastly, the perceptions about roles and responsibilities of professions. In this study, we describe the data according to the four domain in RIPLS, which include teamwork and collaboration, negative professional identity, positive professional identity, and role and responsibility. [16]

[19] The result of the returned questionnaires were concluded into three categories based on total point. If the total point was equal or more than 70 , then the readiness was good. If it was between 44 and 69 then the readiness was moderate. Lastly, if it was less than 44 , the readiness was poor. [17] The data were analysed by using univariate analysis to summarize the readiness of students towards the implementation of IPE.

Table 2. Modified RIPLS item of questionnaire

\begin{tabular}{l}
\hline Questions \\
\hline 1. Learning with other students will help me \\
becoming a more effective member of a health \\
care team
\end{tabular}

2. Patients would ultimately benefit if health-care students worked together to solve patient problems

3. Shared learning with other health-care students will increase my ability to understand clinical problems

4. Learning with health-care students before qualification would improve relationships after qualification

5. Communication skills should be learned with other healthcare students

6. Shared learning will help me to think positively about other professionals

7. For small group learning to work, students need to trust and respect each other

8. Team-working skills are essential for all health care students to learn

9. Shared learning will help me to understand my own limitations

10. I don't want to waste my time learning with other health care students

11. It is not necessary for undergraduate health-care students to learn together

12. Clinical problem-solving skills can only be learned with students from my own department

13. Shared learning with other health-care students will help me to communicate better with patients and other professionals

14. I would welcome the opportunity to work on small-group projects with other health-care students

15. Shared learning will help to clarify the nature of patient problems

16. Shared learning before qualification will help me becoming a better team worker

17. The function of nurses and therapists are mainly to provide support for doctors

18 I'm not sure what my professional role will be

19. I have to acquire much more knowledge and skills than other health-care students 
The data will be presented in form of distributive table to explain the readiness of health faculties' students towards the implementation of IPE.

Ethical permission to explore students' perspective was affirmed by the Ethical Committee of Medical Faculty at Andalas University No.212/KEP/FK/2019.

\section{RESULTS}

A total of 756 students, who came from eight major in five health faculties including preclinical (academic year 2016, 2017, 2018, and 2019) and clinical phase students, were eligible subject of the study. There were more female students were participated in this study
(638 F vs $118 \mathrm{M} ; 84.39 \% \mathrm{~F}$ vs $15.61 \% \mathrm{M}$ ). From the background of major, most students came from medical major $(25.79 \%)$, followed by pharmacy $(15.74 \%)$, dentistry $(13.49 \%)$, public health (12.83\%), nursing (12.57\%), midwifery $(7.80 \%)$, psychology $(6.61 \%)$ and lastly nutrition $(4.76 \%)$. In term of academic phase, students of clinical phase (five majors which have clinical phase) gave 30.69\% (232) from total subjects. More than fifty per cents subject $(58.73 \%)$ were in the age group 20-24 years old. The following group was 15-19 years old $(36.90 \%)$ and the least was in the age group more than 24 years old $(4.37 \%)$.

Table 3. Demographic of Students

\begin{tabular}{|c|c|c|c|c|c|c|c|c|c|c|c|c|c|c|c|c|}
\hline & \multicolumn{2}{|c|}{ Nutrition } & \multicolumn{2}{|c|}{$\begin{array}{l}\text { Public } \\
\text { Health }\end{array}$} & \multicolumn{2}{|c|}{ Psychology } & \multicolumn{2}{|c|}{ Nursing } & \multicolumn{2}{|c|}{ Mid-wifery } & \multicolumn{2}{|c|}{ Dentistry } & \multicolumn{2}{|c|}{ Medical } & \multicolumn{2}{|c|}{ Pharmacy } \\
\hline & $\mathrm{N}$ & $\%$ & $\mathrm{~N}$ & $\%$ & $\mathrm{~N}$ & $\%$ & $\mathrm{~N}$ & $\%$ & $\mathrm{~N}$ & $\%$ & $\mathrm{~N}$ & $\%$ & $\mathrm{~N}$ & $\%$ & $\mathrm{~N}$ & $\%$ \\
\hline \multicolumn{17}{|l|}{ Age } \\
\hline 15-19 y.o. & 23 & 58.97 & 53 & 54.63 & 29 & 58.00 & 35 & 36.84 & 22 & 37.29 & 20 & 19.61 & 56 & 28.72 & 41 & 34.45 \\
\hline 20-24 y.o. & 16 & 41.03 & 44 & 45.36 & 21 & 42.00 & 57 & 60.00 & 32 & 54.24 & 66 & 64.70 & 131 & 67.18 & 77 & 64.71 \\
\hline$>24$ y.o. & 0 & 0 & 0 & 0 & 0 & 0 & 3 & 3.16 & 5 & 8.47 & 16 & 15.69 & 8 & 4.10 & 1 & 0.84 \\
\hline \multicolumn{17}{|l|}{ Gender } \\
\hline Male & 3 & 7.70 & 10 & 10.31 & 8 & 16.00 & 4 & 4.21 & 0 & 0 & 15 & 14.71 & 65 & 33.33 & 13 & 10.92 \\
\hline Female & 36 & 92.30 & 87 & 89.69 & 42 & 84.00 & 91 & 95.79 & 59 & 100 & 87 & 85.29 & 130 & 66.67 & 106 & 89.08 \\
\hline \multicolumn{17}{|l|}{ Batch } \\
\hline 2019 & 17 & 43.59 & 27 & 27.84 & 16 & 32.00 & 21 & 22.10 & 10 & 16.95 & 12 & 11.76 & 29 & 14.87 & 19 & 15.97 \\
\hline 2018 & 12 & 30.77 & 30 & 30.93 & 13 & 26.00 & 16 & 16.84 & 10 & 16.95 & 12 & 11.76 & 29 & 14.87 & 19 & 15.97 \\
\hline 2017 & 8 & 20.51 & 21 & 21.64 & 12 & 24.00 & 16 & 16.84 & 9 & 15.25 & 12 & 11.76 & 29 & 14.87 & 18 & 15.13 \\
\hline 2016 & 2 & 5.13 & 19 & 19.59 & 9 & 18.00 & 11 & 11.58 & 9 & 15.25 & 10 & 9.80 & 28 & 14.36 & 19 & 15.97 \\
\hline Clinical & - & - & - & - & - & - & 31 & 32.63 & 21 & 35.59 & 56 & 54.90 & 80 & 41.03 & 44 & 36.97 \\
\hline
\end{tabular}

In every major, mostly students who participated in this study were in aged group 20-24 years old, except those from three majors; nutrition, public health, and psychology whom mostly aged between 15-19 years old. The readiness among the health faculty students based on this study showed a good result. The majority of the students had a good perception and showing readiness toward the implementation of IPE $(88.36 \%)$. The other $11.51 \%$ students reflected having moderate level of readiness and only one student shown a poor readiness by the result of RIPLS. The comparison between readiness's in both genders had shown a bigger number of female students with good readiness than male students. It was affected by the fact that the distribution of gender wasn't balance enough, presented by ratio of female to male almost 5.5 to 1. Based on its distribution, $83.90 \%$ male students had good perceptions while the remains $16.10 \%$ were in moderate one. In the group of female students, $89.97 \%$ had good readiness, $9.87 \%$ had moderate readiness, and lastly $0.16 \%$ had poor readiness.
Table 4. Distribution of Students' Readiness by Majors

\begin{tabular}{|c|c|c|c|c|c|c|}
\hline & \multicolumn{6}{|c|}{ Readiness } \\
\hline & \multicolumn{2}{|l|}{ Good } & \multicolumn{2}{|c|}{ Moderate } & \multicolumn{2}{|c|}{ Poor } \\
\hline & $\mathrm{N}$ & $\%$ & $\mathrm{~N}$ & $\%$ & $\mathrm{~N}$ & $\%$ \\
\hline \multicolumn{7}{|l|}{ Pre-clinical Phase } \\
\hline Nutrition & 38 & 97.44 & 1 & 2.56 & 0 & 0.00 \\
\hline Public Health & 87 & 89.69 & 9 & 9.28 & 1 & 1.03 \\
\hline Psychology & 41 & 82.00 & 9 & 18.00 & 0 & 0.00 \\
\hline Nursing & 61 & 95.31 & 3 & 4.69 & 0 & 0.00 \\
\hline Midwifery & 38 & 100 & 0 & 0.00 & 0 & 0.00 \\
\hline Dentistry & 42 & 91.30 & 4 & 8.70 & 0 & 0.00 \\
\hline Medical & 110 & 95.65 & 5 & 4.35 & 0 & 0.00 \\
\hline Pharmacy & 67 & 89.33 & 8 & 10.67 & 0 & 0.00 \\
\hline \multicolumn{7}{|l|}{ Clinical Phase } \\
\hline Nursing & 31 & 100 & 0 & 0.00 & 0 & 0.00 \\
\hline Midwifery & 21 & 100 & 0 & 0.00 & 0 & 0.00 \\
\hline Dentistry & 44 & 78.57 & 12 & 21.43 & 0 & 0.00 \\
\hline Medical & 56 & 70.00 & 24 & 30.00 & 0 & 0.00 \\
\hline Pharmacy & 43 & 97.73 & 1 & 2.27 & 0 & 0.00 \\
\hline
\end{tabular}

Table 4 shows the most subjects with good readiness came from pre-clinical phase of midwifery students, clinical 
nursing students, and clinical midwifery students $(100 \%$ respectively). While the lowest number of students with good readiness came from clinical medical students (70\%). The clinical phase medical students had the most students with moderate readiness $(30.00 \%)$, followed by dentistry $(21.43 \%)$ and psychology $(18.00 \%)$. The only major with poor readiness was the public health $(1.03 \%)$.

Table 5. Students' Readiness based on Admission Batch

\begin{tabular}{lllllll}
\hline Batch & \multicolumn{9}{c}{ Readiness } \\
\cline { 2 - 7 } & \multicolumn{2}{c}{ Good } & \multicolumn{2}{c}{ Moderate } & \multicolumn{2}{c}{ Poor } \\
& N & $\%$ & N & $\%$ & N & $\%$ \\
\hline $\mathbf{2 0 1 6}$ & 98 & 91.59 & 8 & 7.48 & 1 & 0.93 \\
$\mathbf{2 0 1 7}$ & 109 & 87.20 & 16 & 12.80 & 0 & 0.00 \\
$\mathbf{2 0 1 8}$ & 134 & 95.04 & 7 & 4.96 & 0 & 0.00 \\
$\mathbf{2 0 1 9}$ & 143 & 94.70 & 8 & 5.30 & 0 & 0.00 \\
Clinical phase & 195 & 84.05 & 37 & 15.95 & 0 & 0.00 \\
\hline
\end{tabular}

Generally, every batch is ready to implement IPE. It is seen by the highest frequency of students with good readiness in every batch. However, the clinical phase students had the lowest amount of students with good readiness $(84.05 \%)$, in contrary with Batch 2018 (95.04\%). But the only one who contributed to poor readiness was Batch 2016 (0.93\%).

As mentioned before, RIPLS have four domains. This study showed that students from each health major had similar opinion about every domain in RIPLS. The students mostly had good opinion about each domain. However, the medical students showed the closest gap between students number in good with moderate one, except in "Teamwork and Collaboration" domain, where the nutrition's students had the closest one. Only Public Health students had poor opinion about "Teamwork and Collaboration" domain (2.1\%) and "Positive Professional Identity" domain (2.1\%). Meanwhile, in "Positive Professional Identity" domain, Public Health students and Medical students had poor opinion $(2.1 \%$ and $1 \%$ respectively). In addition, the medical students also had poor opinion with "Role and Responsibility" domain along with Pharmacy's students ( $0.5 \%$ and $0.8 \%$ respectively).

Table 6. Distribution on RIPLS Domain

\begin{tabular}{|c|c|c|c|c|c|c|c|c|}
\hline \multirow{2}{*}{ Domain } & \multicolumn{8}{|c|}{ Major } \\
\hline & $\mathrm{N}$ & $\mathrm{PH}$ & PS & $\mathrm{Nr}$ & MW & $\mathrm{D}$ & M & $\mathrm{P}$ \\
\hline \multicolumn{9}{|c|}{ Teamwork and Collaboration } \\
\hline Good & 28 & 93 & 42 & 92 & 59 & 96 & 179 & 113 \\
\hline $\mathrm{N}(\%)$ & $(71.8)$ & $(95.8)$ & (84) & $(96.8)$ & $(100)$ & $(94.1)$ & $(91.8)$ & $(95)$ \\
\hline Moderate & 11 & 2 & 8 & 3 & 0 & 6 & 16 & 6 \\
\hline $\mathrm{N}(\%)$ & $(28.2)$ & $(2.1)$ & $(16)$ & $(3.2)$ & $(0)$ & $(5.9)$ & $(8.2)$ & (5) \\
\hline Poor & 0 & 2 & 0 & 0 & 0 & 0 & 0 & 0 \\
\hline $\mathrm{N}(\%)$ & $(0)$ & $(2.1)$ & $(0)$ & $(0)$ & $(0)$ & $(0)$ & $(0)$ & $(0)$ \\
\hline \multicolumn{9}{|c|}{ Negative Professional Identity } \\
\hline Good & 28 & 81 & 39 & 84 & 53 & 74 & 131 & 93 \\
\hline $\mathrm{N}(\%)$ & $(71.8)$ & $(83.5)$ & (78) & $(88.4)$ & $(89.8)$ & $(72.5)$ & $(67.2)$ & $(78.2)$ \\
\hline Moderate & 11 & 12 & 9 & 10 & 6 & 24 & 53 & 21 \\
\hline $\mathrm{N}(\%)$ & $(28.2)$ & $(12.4)$ & $(18)$ & $(10.5)$ & $(10.2)$ & $(23.5)$ & $(27.2)$ & (17.6) \\
\hline Poor & 0 & 4 & 2 & 1 & 0 & 4 & 11 & 5 \\
\hline $\mathrm{N}(\%)$ & $(0)$ & $(4.1)$ & (4) & $(1.1)$ & $(0)$ & (4) & $(5.6)$ & $(4.2)$ \\
\hline \multicolumn{9}{|c|}{ Positive Professional Identity } \\
\hline Good & 38 & 87 & 32 & 91 & 54 & 87 & 163 & 108 \\
\hline $\mathrm{N}(\%)$ & $(97.4)$ & $(89.7)$ & (64) & $(95.8)$ & $(91.5)$ & $(85.3)$ & $(83.6)$ & $(90.8)$ \\
\hline Moderate & 1 & 8 & 18 & 4 & 5 & 15 & 30 & 11 \\
\hline $\mathrm{N}(\%)$ & $(2.6)$ & $(8.2)$ & (36) & $(4.2)$ & $(8.5)$ & $(4.7)$ & $(15.4)$ & $(9.2)$ \\
\hline Poor & 0 & 2 & 0 & 0 & 0 & 0 & 2 & 0 \\
\hline $\mathrm{N}(\%)$ & $(0)$ & $(2.1)$ & $(0)$ & $(0)$ & $(0)$ & $(0)$ & (1) & $(0)$ \\
\hline \multicolumn{9}{|c|}{ Role and Responsibility } \\
\hline Good & 18 & 56 & 26 & 77 & 47 & 54 & 100 & 82 \\
\hline $\mathrm{N}(\%)$ & $(46.2)$ & $(57.7)$ & $(52)$ & $(81.1)$ & $(79.7)$ & $(52.9)$ & $(51.3)$ & (68.9) \\
\hline Moderate & 21 & 41 & 24 & 18 & 12 & 48 & 94 & 36 \\
\hline $\mathrm{N}(\%)$ & (53.8) & $(42.3)$ & (48) & (18.9) & (20.3) & $(47.1)$ & $(48.2)$ & (30.3) \\
\hline Poor & 0 & 0 & 0 & 0 & 0 & 0 & 1 & 1 \\
\hline $\mathrm{N}(\%)$ & $(0)$ & $(0)$ & (0) & $(0)$ & $(0)$ & (0) & $(0.5)$ & $(0.8)$ \\
\hline
\end{tabular}


Female students got higher point in total RIPLS compared to male students. They also had greater score in 'Teamwork and collaboration' and 'Positive professional identity'. In term of batch, the seniors students had fewer score of RIPLS compared to early year students. Therefore, the highest total RIPLS score was assessed in Batch 2016 and the fewest was clinical phase's students. The score of each domain also followed the same pattern. Midwifery students had highest total RIPLS score, followed by Nursing and Pharmacy. Meanwhile, the lowest of total RIPLS score was medical students.

Table 7. Description of RIPLS Score

\begin{tabular}{|c|c|c|c|c|c|}
\hline & $\begin{array}{l}\text { Total } \\
\text { RIPL } \\
\text { (Mean } \\
\pm \text { SD) }\end{array}$ & $\begin{array}{c}\text { T\&C } \\
\text { (Mean } \\
\pm \text { SD) }\end{array}$ & $\begin{array}{c}\text { NPI } \\
\text { (Mean } \\
\pm \text { SD) }\end{array}$ & $\begin{array}{c}\text { PPI } \\
\text { (Mean } \\
\pm \text { SD) }\end{array}$ & $\begin{array}{c}\text { R\&R } \\
\text { (Mean } \\
\pm \text { SD) }\end{array}$ \\
\hline \multicolumn{6}{|l|}{ Gender } \\
\hline Male & $77 \pm 9.99$ & $\begin{array}{c}38 \pm \\
5.33\end{array}$ & $\begin{array}{c}12 \pm \\
2.60\end{array}$ & $\begin{array}{c}16 \pm \\
2.63\end{array}$ & $\begin{array}{r}11 \pm \\
1.86\end{array}$ \\
\hline \multirow[t]{2}{*}{ Female } & $79 \pm$ & $39 \pm$ & $12 \pm$ & $17 \pm$ & $11 \pm$ \\
\hline & 8.24 & 4.19 & 2.41 & 2.23 & 1.90 \\
\hline \multicolumn{6}{|l|}{ Batch } \\
\hline \multirow[t]{2}{*}{2016} & $79 \pm$ & $39 \pm$ & $12 \pm$ & $17 \pm$ & $11 \pm$ \\
\hline & 9.79 & 5.34 & 2.24 & 2.55 & 1.90 \\
\hline \multirow[t]{2}{*}{2017} & $79 \pm$ & $39 \pm$ & $12 \pm$ & $17 \pm$ & $11 \pm$ \\
\hline & 7.79 & 3.97 & 1.96 & 2.17 & 1.94 \\
\hline \multirow[t]{2}{*}{2018} & $81 \pm$ & $40 \pm$ & $12 \pm$ & $17 \pm$ & $11 \pm$ \\
\hline & 7.63 & 3.89 & 2.46 & 2.03 & 1.86 \\
\hline \multirow[t]{2}{*}{2019} & $81 \pm$ & $40 \pm$ & $12 \pm$ & $17 \pm$ & $11 \pm$ \\
\hline & 8.05 & 3.98 & 2.30 & 2.24 & 1.90 \\
\hline \multirow[t]{2}{*}{ Clinical } & $77 \pm$ & $38 \pm$ & $11 \pm$ & $16 \pm$ & $11 \pm$ \\
\hline & 8.71 & 4.57 & 2.69 & 2.34 & 1.89 \\
\hline \multicolumn{6}{|l|}{ Major } \\
\hline \multirow[t]{2}{*}{ Nutrition } & $79 \pm$ & $39 \pm$ & $12 \pm$ & $17 \pm$ & $11 \pm$ \\
\hline & 6.82 & 3.69 & 1.98 & 1.94 & 1.42 \\
\hline Public & $79 \pm$ & $39 \pm$ & $12 \pm$ & $17 \pm$ & $11 \pm$ \\
\hline Health & 9.64 & 5.31 & 2.41 & 2.59 & 1.99 \\
\hline \multirow[t]{2}{*}{ Psychology } & $74 \pm$ & $36 \pm$ & $11 \pm$ & $16 \pm$ & $11 \pm$ \\
\hline & 6.99 & 3.41 & 2.19 & 2.17 & 1.67 \\
\hline \multirow[t]{2}{*}{ Nursing } & $80.78 \pm$ & 39.09 & 12.35 & 17.05 & 12.28 \\
\hline & 6.74 & \pm 3.66 & \pm 2.02 & \pm 1.78 & \pm 1.88 \\
\hline \multirow[t]{2}{*}{ Midwifery } & $83.83 \pm$ & 40.90 & 13.03 & 17.71 & 12.19 \\
\hline & 6.79 & \pm 3.35 & \pm 1.77 & \pm 2.13 & \pm 1.73 \\
\hline \multirow[t]{2}{*}{ Dentistry } & $77.73 \pm$ & 38.95 & 11.55 & 16.65 & 10.58 \\
\hline & 8.51 & \pm 4.25 & \pm 2.52 & \pm 2.21 & \pm 1.70 \\
\hline \multirow[t]{2}{*}{ Medical } & $77.41 \pm$ & 38.62 & 11.44 & 16.72 & 10.63 \\
\hline & 9.18 & \pm 4.75 & \pm 2.78 & \pm 2.44 & \pm 1.71 \\
\hline \multirow[t]{2}{*}{ Pharmacy } & $80.74 \pm$ & 40.17 & 11.91 & 17.25 & 11.41 \\
\hline & 8.12 & \pm 4.00 & \pm 2.44 & \pm 2.29 & \pm 1.99 \\
\hline
\end{tabular}

T\&C: Teamwork and collaboration domain; NIP: Negative professional identity domain; PPI: Positive professional identity; R\&R: Role and responsibility domain.

\section{DISCUSSION}

In several studies related to readiness and RIPLS use we found that several studies did not only asses readiness, but also another aspect. [20][21] Study by Woermann et.al., for example, evaluate the attitude towards and readiness for Interprofessional education in medical and nursing students. [20]

Generally, RIPLS score of students in health faculties, University of Andalas was high. Female students had greater score compare to male students. It was similar as Talwalkar et.al. study which found that female students had greater score of RIPLS. [19] A study (19) about readiness among medical, nursing, and PA students showed high RIPLS score. But, nursing students scored significantly higher in total RIPLS. It was a bit different with this study where midwifery scored highest and followed by nursing students. [19] The advanced grade students also scored bigger in RIPLS then earlier grade students. [19] In some studies we found that the advanced grade students scored bigger, like senior level in preclinical or end-level students in internship. [19][22] In contrary, in our study, the advanced grade students scored lower than earlier grade ones. This should put us into special concerns due to needs for clinical students to do collaboration in their study, although they already scored well for readiness. A study concluded that medical students seeing themselves as separated group of health professional in their own. [23] The awareness towards IPE in their education will shape their future practice from early to a good turning point. [24] In other point, it could be a good sign since the earliest grade score highest. The faculties had good starting point to implement IPE, by integrating these concepts into learning process and involving clinical instructors. [22] The end point is improving collaborative practice, teamwork skills, and patients' outcomes. [25]

We assumed that students in health faculties at Andalas University are ready to learn IPE in their curricula. It is based on the majority of students who received good points in RIPLS questionnaire. However, a refreshing idea was brought by Visser et.al. stated that 'Readiness for IPL' should not be considered as standard that students would pass and learn about IPE. It will benefit more to combine the cognitive component of empathy ('Perspective taking') and curriculum' elements in order to students gradually develop ownership of IPE. [18] 


\section{CONCLUSION}

The students of health faculties at Andalas University are ready to implement IPE into their curricula. The students mostly showed good readiness towards the implementation of IPE. Each major perceives every domain in RIPLS positively and similarly. But, the score get fewer as the grade became more advance. In practice, we do hope the willingness and readiness to implement IPE are increased as the target is to work well in collaboration with others professionals in future practices. Thus, there is a need to assess the root of problems which cause the mindset to change during the advancing of education. However, students are not the only component to consider during IPE' implementation. The study should provide the condition of lecturers' readiness in the future along with their attitude towards this implementation. This study cannot explain the relation between every aspect in nurturing readiness of IPE with the characteristic of students. Therefore, future study is

\section{REFERENCES}

[1]. World Health Organization. Framework for Action on Interprofesional Eduction \& Collaborative Practice. Geneva: World Health Organization, Departement of Human Resources for Health, 2010.

[2]. Guraya, SY and Barr, H. The effectiveness of interprofessional education in health cae: A systematic review and meta nalysis. Kaohsiung Journal of Medical Science, Vol. 34, 2018, pp. 160165.

[3]. Devenski, G, Iryani, D and Semiarty, R. Gambaran kesiapan mahasiswa tahap akademik dan dosen program studi profesi dokter Fakultas Kedokteran Universitas Andalas terhadap penerapan Interprofessional Education (IPE). Universitas Andalas. Padang: scholar.unand.ac.id, 2017.

[4]. Prabowo, GA, Khiryati, NA, A'la, MZ, Negara, HP, Hendrawati, YD, Meisudi, R, Yolina, M. Apa Kata Mahasiswa? Hasil kajian partisipasi dan kolaborasi mahasiswa keseahtan di Indonesia. s.l. : HPEQ-Project DIKTI Kementrian Pendidikan dan Kebudayaan, 2012. p. 44

[5]. Reeves, S. The rise and rise of interprofessional competence. Journal of Interprofessional Care, Vol. 26, 2012, pp. 253-255.

[6]. Shirazi, M, Moradi, K, Mehrizi, AAH, Keshmiri, F, Montazeri, A. Readiness to change for interprofessinal collaboration in healthcare: Development and validation of a theory-based instrument. Journal of Interprofessional Care. 2018 needed to solve the issue. The study about IPE in the future, should not only assess the readiness as in the initiation phases of IPE. The evaluation during its implementation and afterward are periodically important for improvement in health education.

\section{ACKNOWLEDGMENT}

We would like to show our gratitude to the students of eight health profession majors at Andalas University Padang, Indonesia. They include the students of medicine, psychology, midwifery, public health, pharmacists, nursing, dentistry and nutrition major for giving us permission to do our research.

This study was supported financially by PNBP 2019 Medical Faculty-University of Andalas. Thank you for Dian Anggraini, Firlando Riyanda, Gaby Devenski, and Indah Noprimasari Yudi for their assistance in conducting the study.

[7]. Yusuf, S. Faculty of Health Sciences: An opportunity fo the implementation of interprofessional education. 2017, Belitung Nursing Journal, Vol. 3.

[8]. Reeves, S, Fletcher, S, Barr, H, Birch, L, Boet, S, Davies, N. A BEME systematic review of the effects of interprofessional education: BEME Guide. 7, s.l. : Medical Teacher, 2016, Vol. 38, pp. 656-668.

[9]. Jacobs, J, Samarasekera, D, Chui, W, Chan, S, Wong, L, Liaw, S, et.al. Building a successful platform for interprofessional education for health professions in an Asian university. s.l. : Education for Health, 2013, Vol. 26.

[10]. Isrona L \& Anggraini D. Interprofessional education in medical and Health science education: reviewing the progress in ASEAN. The $1^{\text {st }}$ IC ASEAN Proceeding. www.content.sciendo.com. 2019.

[11] Lee, B, Shinozaki, H, Bophayanh, K, Tokita, Y, Makino, T, Matsui, H, et.al. A plan for embedding an interprofessional education initiative into an existing programme in a Southeast Asian university. 3, s.l. : Journal of Interprofessional Care, 2016, Vol. 30.

[12]. Lestari, E and Lestari, S. Community based interprofessional learning promotes equality of participation among health professions students. 2, s.l. Online J Health Allied Scs, Vol. 17, 2018.

[13]. Widyandana, D. s.l Evaluating interprofessional education principle in a longitudinal communitybased programs for 3 schools of health professions: medicine, nursing, and nutrition.The Indonesian 
Jounal of Medical Education, Vol. 7, 2018.

[14]. Susanti, D, Wulandari, H, Juaeriah, R, Dewi, S. Penerapan interprofessional education (IPE) pada kelas ibu balita oleh mahasiswa tenaga kesehatan untuk meningkatkan sikap ibu terhadap kesehatan balita di kota CImahi. JSK, Vol. 3, 2017.

[15]. Toman, K, Probandari, A and Timor, A. s.1.The interprofessional education (IPE): The community outcomes of health sevices within collaboration practices in Faculty of Medicine, Sebelas Maret University. Nexus Pendidikan Kedokteran dan Kesehatan, Vol. 5, 2016.

[16]. Parsell, G and Bligh, J. s.l. The development of a questionnaire to assess the readiness of health care students for interprofessional learning (RIPLS).

Medical Education, Vol. 33, , 1999. pp. 95-100.

[17]. Fauziah, FA. Analisis gambaran persepsi dan kesiapan mahasiswa profesi FK UGM terhadap interpofessional education. Yogyakarta : Universitas Gajah Mada, 2009.

[18]. Visser, CLF, Wilschut, JA, van der Burgt, SME, Croiset, G, Kusukar, RA. The association of Readiness for Interprofessional Learning with empath, motivation and professional identity evelopment in medical students. BMC Medical Education, Vol. 18, 2018.

[19]. Talwalkar, JS, Fahs, DB, Kayingo, G, Wong, R, Jeon, S, Honan, L. Readiness for interprofessional learning among healthcare professional students. Vol. 7, 2016, pp. 144-148.

[20]. Woermann, Weltsch, L, Kunz, A, Stricker, D, Guttormsen, SAttitude towards and Readiness for Interprofessional Education in Medical and Nursing Students of Bern. GMS Journal of Medical Education, Vol. 33, 2016.

[21]. Rossler, KL and Kimble, LP. Capturing readiness to learn and collaboration as explored with an interprofessional simulation scenario: A mixed-methods research study, Nurse Educ Today,2015.

[22]. Salih, S, Gameraddin, M, Kamal, S, Alsadi, M, Tamboul, J, Alsultan, $\mathbf{K}$. The readiness for interprofessional education (IPE) in the school setting among the internship students of applied medical sciences at Taibah University. Advances in Medical Education Practice, 2019, pp. 843-848.

[23]. Roopnarine, R and Boeren, E. Applying the Readiness for Interprofessional Learning Scale (RIPLS) to medical, veterinary and dual degree Master of Public Health (MPH) students at a private medical institution. Plos ONE, Vol. 15, 2020.
[24]. Call for Papers. The historical context of interprofessional education and collaboration. J interprof care, Vol. 26, 2012, pp. 353-354.

[25]. Reeves, S, MacMillan, K and Van Soeren, M Leadership within interprofessional health and social care teams: a socio-hystorical analysis of key trials and tribulation. J Nurs Manag, Vol. 18, 2010. pp. 258-264. 